\title{
Article \\ The Effects of Reduced Mineral Fertilisation Combined with the Foliar Application of Biostimulants and Fertilisers on the Nutrition of Maiden Apple Trees and the Contents of Soil Nutrients
}

\author{
Sławomir Świerczyński * ${ }^{*}$ and Agnieszka Antonowicz \\ Department of Ornamental Plants, Dendrology and Pomology, Poznan University of Life Sciences, \\ Dąbrowskiego 159, 60-594 Poznan, Poland; agnieszka.studiom2@gmail.com \\ * Correspondence: slawomir.swierczynski@up.poznan.pl; Tel.: +48-61848-7954
}

check for updates

Citation: Świerczyński, S.; Antonowicz, A. The Effects of Reduced Mineral Fertilisation Combined with the Foliar

Application of Biostimulants and Fertilisers on the Nutrition of Maiden Apple Trees and the Contents of Soil Nutrients. Agronomy 2021, 11, 2438. https://doi.org/10.3390/agronomy 11122438

Academic Editor: Yoshiharu Fuji

Received: 9 November 2021

Accepted: 25 November 2021

Published: 29 November 2021

Publisher's Note: MDPI stays neutral with regard to jurisdictional claims in published maps and institutional affiliations.

Copyright: (c) 2021 by the authors. Licensee MDPI, Basel, Switzerland. This article is an open access article distributed under the terms and conditions of the Creative Commons Attribution (CC BY) license (https:// creativecommons.org/licenses/by/ $4.0 /)$.

\begin{abstract}
The experiment compared the use of a dose of mineral fertilisation reduced by half in a nursery, which was replaced by foliar treatment with biostimulants and fertilisers. The control combination was a full dose of mineral fertilisation without foliar treatments. The half dose of mineral fertiliser applied into the soil decreased its acidity and salinity. At the same time, it decreased the soil content of macro- and micronutrients, except for calcium and iron. In most cases the simultaneous foliar application of the four biostimulants tested in our experiment reduced the content of macronutrients in the leaves of maiden apple trees, except for calcium. On the other hand, it increased the iron (28.2\% average) and manganese (24.8\% average) levels in the leaves but reduced the levels of zinc ( $11.8 \%$ average) and copper ( $25 \%$ average). The foliar application of two fertilisers increased the leaf contents of phosphorus (12\% average) and calcium (9.3\% average). One of the fertilisers also increased the leaf contents of potassium, magnesium, and micronutrients.
\end{abstract}

Keywords: nursery; mineral fertiliser dosage; leaves; soil; content of macro- and micronutrients

\section{Introduction}

Poland is the largest producer of maiden apple trees in Europe and the third largest apple producer in the world. Large amounts of mineral fertilisers are used in nursery production to intensify the vegetative growth of fruit trees. On the other hand, plants do not use large amounts of nutrients supplied with mineral fertilisers, because these are leached into deeper soil layers, where they degrade the environment [1-4]. Plants can absorb more nutrients at a faster rate if foliar fertilisation is applied, especially at low temperatures $[5,6]$. According to some authors $[1,7,8]$, the combination of these two methods of plant nutrition guarantees the best results in the cultivation of apple trees. Foliar fertilisation should be practised due to the insufficient uptake of soil nutrients during periods of low rainfall [9]. It should also be applied if plants' roots are damaged and during stagnation of water on the soil surface. This method of fertilisation is particularly important for magnesium and calcium supplementation deficiencies, because the root absorption of these nutrients is limited due to their antagonistic relationship with other elements [10,11].

Biostimulants change the solubility and transport activity of nutrients supplied to plants $[12,13]$. As results from the research conducted so far, the foliar application of marine algae extracts stimulated the uptake of nutrients in various plant species, e.g., lettuce and grape [14], soybean [15], tomato [16], and winter rapeseed [17]. The treatment increased the contents of both macro- $(\mathrm{N}, \mathrm{P}, \mathrm{K}, \mathrm{Ca}, \mathrm{S})$ and micronutrients $(\mathrm{Mg}, \mathrm{Zn}, \mathrm{Mn}, \mathrm{Fe})$ in these plants. Some researchers $[14,15,18]$ observed that these biostimulants increased the leaf potassium content. In contrast, Shehata et al. [19] found that the seaweed extract had no effect on the potassium content in celeriac leaves. Additionally, Filipczak et al. [20] did not observe any significant effect of various biostimulants on the contents of minerals in strawberry 
leaves. Furuya et al. [21] observed that the application of amino-acid-based biostimulants increased the uptake of nutrients by peach plants. According to De Pascale et al. [22], natural bioactive substances and microbial inoculants may be valuable tools that enhance the availability of soil nutrients, their uptake, and their assimilation.

Multi-component fertilisers are usually used in foliar spray treatments. The influence of foliar fertilisation on the growth of maiden apple trees in a nursery was studied by Świerczyński and Stachowiak [23]. However, neither of the fertilisers (urea, calcium nitrate) used in their experiment improved the growth of the maiden apple trees significantly. In a later study [24], only one of the foliar fertilisers (Maxi Grow Excel) used in the experiment improved the growth of maiden cherry trees. Other foliar preparations and fertilisers, which also contained microelements (Black Jack and Biopuls Forte), increased the contents of nitrogen and phosphorus, and less frequently the contents of potassium, calcium, and micronutrients in the leaves of maiden sweet cherry trees. Other authors [25] used two fertilisers (Florovit Eko and Florovit Pro Natura) and observed increased potassium contents in the leaves of maiden apple and cherry trees.

The aim of experiment was to compare the results of the contents of soil nutrients fertilised with a full dose and half dose of mineral fertilisers used in the production of maiden apple trees in a nursery. Additionally, we compared the contents of macro- and micronutrients in the leaves of maiden apple trees after the application of a reduced dose of mineral fertilisers in combination with foliar treatment with selected biostimulants and fertilisers in relation to the full dose without these treatments. The presented results of the experiment complement the previously described effects of a reduced dose of mineral fertilisation with spraying treatment with biostimulants and fertilisers on the growth of maiden apple trees, to which the authors refer in the present publication.

\section{Materials and Methods}

\subsection{Plant Material and Growth Conditions}

The experiment was conducted on one-year-old maiden apple trees of four varieties, 'Gala Schniga', 'Ligol', 'Red Boskoop', and 'Topaz', grown in a nursery on an M.9 rootstock. Between 2017 and 2018, two separate series of the experiment were conducted. The experiment was carried out on two parallel plots in the nursery. On one of them, full mineral fertilisation $\left(120 \mathrm{~N} \cdot \mathrm{h}^{-1}, 40 \mathrm{P}_{2} \mathrm{O}_{5} \cdot \mathrm{h}^{-1}, 140 \mathrm{~K}_{2} \mathrm{O} \cdot \mathrm{h}^{-1}\right)$, was applied and four varieties of maiden apple trees were grown, which were not treated with foliar treatment during their growth. In the second plot, the dose of mineral fertilisation was reduced by half $\left(60 \mathrm{~N} \cdot \mathrm{h}^{-1}, 20 \mathrm{P}_{2} \mathrm{O}_{5} \cdot \mathrm{h}^{-1}, 70 \mathrm{~K}_{2} \mathrm{O} \cdot \mathrm{h}^{-1}\right)$, and foliar treatments with four biostimulators and two fertilisers were applied during the growth of maiden trees of four apple varieties. During the cultivation of the maiden trees of individual cultivars, six foliar feeding combinations were randomly distributed in the second plot. Before the nursery was established, the soil was analysed chemically, containing the following amounts of soluble forms of macronutrients: $87 \mathrm{mg} \cdot \mathrm{dm}^{-3}$ phosphorus, $113 \mathrm{mg} \cdot \mathrm{dm}^{-3}$ potassium, $485 \mathrm{mg} \cdot \mathrm{dm}^{-3}$ calcium, and $83 \mathrm{mg} \cdot \mathrm{dm}^{-3}$ magnesium (mean value for 2017-2018). The total rainfall volumes in individual years of the study were $338 \mathrm{~mm}$ (2017) and $228 \mathrm{~mm}$ (2018).

\subsection{Biostimulants and Fertiliser Experiment}

Four biostimulants were applied at the concentrations recommended by the manufacturer (Aminoplant $0.4 \%$, Biamino Plant $0.2 \%$, Bispeed $0.2 \%$, Fylloton $0.4 \%$ ). Two foliar fertilisers (Basfoliar 6-12-6 and Basfoliar 4-6-12 + S) were applied at a concentration of 0.5\% $\left(5 \mathrm{~mL} \cdot 1^{-1}\right)$.

Aminoplant contained $18 \mathrm{~L}$-amino acids and bioactive peptides $(\mathrm{N} 8.5 \%$; organic substances $54 \%$ : bioactive peptides $82.7 \%$, amino acids $17.3 \%$ ). The composition of Biamino Plant was dominated by L-amino acids of plant origin (organic nitrogen $7.6 \%$, organic carbon $21.0 \%$, amino acids $42.6 \%$, Fe $1.2 \%$, Mn 0.6\%, Zn 0.7\%). Bispeed was composed of potassium 4-nitrophenolate $0.25-0.30 \% \mathrm{~m} / \mathrm{m}$, potassium 2-nitrophenolate $0.14-0.20 \%$ $\mathrm{m} / \mathrm{m}$, and potassium 5-nitroguaiacolate $0.07-0.10 \% \mathrm{~m} / \mathrm{m}$. Fylloton contained brown algae 
extract (Ascophyllum nodosum) and plant-derived amino acids (organic nitrogen $6 \%$, organic carbon $20.8 \%$, organic substance $35 \%$ ). Basfoliar 6-12-6 is a multi-component liquid foliar fertiliser composed of $\mathrm{N} 6 \%, \mathrm{P}_{2} \mathrm{O}_{5} 12 \%, \mathrm{~K}_{2} \mathrm{O} 6 \%$, B $0.01 \%$, Cu $0.01 \%$, Fe $0.02 \%, \mathrm{Mn} 0.01 \%$, Mo $0.005 \%$, Zn 0.05\%. Basfoliar 12-4-6+S was composed of: $\mathrm{N} \mathrm{12 \% ,} \mathrm{P}_{2} \mathrm{O}_{5} 4 \%, \mathrm{~K}_{2} \mathrm{O} 6 \%$, sulphur, and all microelements. Each of the twenty-eight experimental combinations (four biostimulants, two fertilisers, one control combination, and 4 varieties of apple) was represented in one plot by ten maiden trees in triplicate. Between early May and late July, the plants were sprayed with the biostimulants and fertilisers four times at three-week intervals. The control plants were treated with distilled water only. A $0.2 \%$ Slippa adjuvant was added to the solution with which the maiden trees were treated.

\subsection{Chemical Analyses}

In each year, the experiment soil samples were collected for chemical analyses in late July. Collected samples of the substrate were chemically analysed using the universal method. Extraction of macronutrients $\left(\mathrm{N}^{-\mathrm{NH}_{4}}, \mathrm{~N}-\mathrm{NO}_{3}, \mathrm{P}, \mathrm{K}, \mathrm{Ca}, \mathrm{Mg}, \mathrm{S}-\mathrm{SO}_{4}\right), \mathrm{Cl}$, and $\mathrm{Na}$ was carried out in $0.03 \mathrm{M} \mathrm{CH}_{3} \mathrm{COOH}$ with a quantitative 1:10 ratio of substrate to extraction solution. After extraction, the following determinations were made: $\mathrm{N}-\mathrm{NH}_{4}, \mathrm{~N}-\mathrm{NO}_{3}$-by microdistillation according to Bremer in Starck's modification; P-colorimetrically with ammonium vanadomolybdate; $\mathrm{K}, \mathrm{Ca}, \mathrm{Na}$ - photometrically; $\mathrm{Mg}$ - by atomic absorption spectrometry (ASA); $\mathrm{S}-\mathrm{SO}_{4}$-nephelometrically with $\mathrm{BaCl}_{2} ; \mathrm{Cl}$-nephelometrically with $\mathrm{AgNO}_{3}$. Micronutrients (Fe, $\mathrm{Mn}, \mathrm{Zn}, \mathrm{Cu}$ ) were extracted from the soil with Lindsay's solution, which in $1 \mathrm{dm}^{3}$ contained: $5 \mathrm{~g}$ EDTA (ethylenediaminetetraacetic acid); $9 \mathrm{~cm}^{3}$ of $25 \%$ $\mathrm{NH}_{4}$ solution, $4 \mathrm{~g}$ citric acid; $2 \mathrm{~g} \mathrm{Ca}\left(\mathrm{CH}_{3} \mathrm{COO}\right)_{2} \cdot 2 \mathrm{H}_{2} \mathrm{O}$. Micronutrients were determined using the ASA method. Salinity was identified conductometrically as electrolytic conductivity $\left(\mathrm{EC}\right.$ in $\left.\mathrm{mS} \cdot \mathrm{cm}^{-1}\right)($ substrate/water $=1: 2)$ and $\mathrm{pH}$ was determined by potentiometric method (substrate/water $=1: 2$ ). In early August in both years of the research, samples of leaves were collected from the middle part of the long shoots of randomly selected maiden trees for analyses of the contents of macro- and micronutrients. The total nitrogen content was measured with the Kjeldahl method on a Parnas-Wagner apparatus. The phosphorus content was measured with the colorimetric method with ammonium molybdate. The potassium and calcium contents were measured using flame photometry, whereas the magnesium content was measured with atomic absorption. The content of macronutrients was expressed as a percentage. The content of the total forms of micronutrients, such as iron, zinc, manganese, and copper (ppm), was measured by means of atomic absorption spectrometry (ASA) after wet mineralisation of $2.5 \mathrm{~g}$ samples in a mixture of nitric acid and perchloric acid at a volume ratio of 3:1.

\subsection{Data Analysis}

The results of the study were analysed with STATISTICA 13.1 (Statsoft Polska, Kraków, Poland). Homogeneous groups for individual traits and treatments were calculated with Tukey's HSD test. The statistical significance level was $p=0.05$. The results of measurements of the mineral elements were analysed separately by means of two-way analyses of variance, where the apple tree cultivars and foliar treatments were the factors.

\section{Results}

\subsection{Chemical Analysis of Soil Samples from Nursery with Maiden Apple Trees}

The experiment compared the effects of two doses of mineral fertilisers, full and half, on the contents of nutrients in the soil, where all applied foliar treatments constituted one group with a half dose. The soil treated with half the dose of the mineral fertiliser had lower $\mathrm{pH}$ and exceeded the optimal $\mathrm{pH}$ level for apple tree growing (6.3-6.7) (Table 1). The soil treated with lower doses of the fertiliser had higher $\mathrm{Na}$ and $\mathrm{Cl}$ contents but lower salinity and $\mathrm{S}_{-} \mathrm{SO}_{4}$ contents. 
Table 1. The salinity and $\mathrm{pH}$ of the soil and the contents of soluble forms of $\mathrm{Na}, \mathrm{Cl}$, and S-SO4 in nursery soil (mean value for 2017-2018).

\begin{tabular}{ccccccc}
\hline $\begin{array}{c}\text { Dose of Mineral } \\
\text { Fertilisation }\end{array}$ & $\mathbf{p H}$ & $\begin{array}{c}\mathbf{E C} \\
\left(\mathbf{m S} \cdot \mathbf{c m}^{-\mathbf{1}}\right)\end{array}$ & $\mathbf{N a}$ & $\mathbf{C l}$ & $\mathbf{S}^{-S_{0}}$ \\
\hline Full & 6.40 & 0.27 & 14 & 4.4 & 6 \\
\hline Half & 7.19 & 0.065 & 17 & 8 & 5 \\
\hline
\end{tabular}

The content of ammoniacal nitrogen in the soil treated with half the dose of the mineral fertiliser was lower than the full dose. There were only traces of the nitrate form in both experimental variants (Table 2). The contents of phosphorus, potassium, and magnesium in the soil treated with the full dose of the fertiliser were respectively $75 \%, 50 \%$, and about $30 \%$ greater than in the soil treated with half the dose of mineral fertiliser. The contents of individual components in the soil were compared with the ranges recommended by Breś et al. [26] for mineral soils used for the cultivation of horticultural crops.

The phosphorus content exceeded the average value recommend by Breś et al. [26] with both doses of the mineral fertiliser. The reduced dose of fertiliser resulted in a low potassium content, although the full dose resulted in a high content of this element. Lipiński [27] observed that the magnesium content did not reach the average level when a reduced dose of fertiliser was applied, although Breś et al. [26] noted increased levels of this element in both cases. The soil treated with a reduced dose of the mineral fertiliser had a higher calcium content. The $\mathrm{K} / \mathrm{Mg}$ ratio was correct and amounted to 1.5 at the full dose of the mineral fertiliser and 1.1 at the reduced dose.

Table 2. The contents of soluble forms of N-NH4, N-NO3, P-PO4, K, Ca, and Mg in nursery soil (mean values for 2017-2018).

\begin{tabular}{|c|c|c|c|c|c|c|}
\hline \multirow{2}{*}{$\begin{array}{l}\text { Dose of Mineral } \\
\text { Fertilisation }\end{array}$} & \multirow{2}{*}{$\mathrm{N}-\mathrm{NH}_{4}$} & \multirow{2}{*}{$\mathrm{N}-\mathrm{NO}_{3}$} & $\mathbf{P}$ & $\mathbf{K}$ & $\mathrm{Ca}$ & $\mathbf{M g}$ \\
\hline & & & \multicolumn{4}{|c|}{$\left(\mathrm{mg} \cdot \mathrm{dm}^{-3}\right)$} \\
\hline Full & 28 & $\begin{array}{c}\text { trace } \\
\text { amounts }\end{array}$ & 107 & 145 & 520 & 96 \\
\hline Half & $\begin{array}{l}\text { trace } \\
\text { amounts }\end{array}$ & $\begin{array}{c}\text { trace } \\
\text { amounts }\end{array}$ & 82 & 69 & 675 & 65 \\
\hline
\end{tabular}

The iron level was higher in the soil treated with the lower dose of mineral fertiliser (Table 3). However, this soil had lower contents of manganese, zinc, and copper. The contents of micronutrients for both doses of the fertiliser were as follows: Fe-below optimal; Mn—above optimal (optimal range: $20-40 \mathrm{mg} \cdot \mathrm{dm}^{-3}$ ); $\mathrm{Zn}-$ within optimal and high (optimal range: $5-20 \mathrm{mg} \cdot \mathrm{dm}^{-3}$ ); $\mathrm{Cu}$-optimal (optimal range: 2.0-5.0 $\left.\mathrm{mg} \cdot \mathrm{dm}^{-3}\right)$.

Table 3. The contents of soluble forms of $\mathrm{Fe}, \mathrm{Mn}, \mathrm{Zn}$, and $\mathrm{Cu}$ in nursery soil (mean values for 2017-2018).

\begin{tabular}{ccccc}
\hline \multirow{2}{*}{ Dose of Mineral Fertilisation } & Fe & Mn & Zn & Cu \\
\cline { 2 - 5 } & \multicolumn{4}{c}{$\mathbf{( m g \cdot \mathbf { d m } ^ { - 3 } )}$} \\
\hline Full & 115.9 & 73.7 & 21.2 & 3.9 \\
\hline Half & 121.9 & 70.4 & 18.3 & 2.6 \\
\hline
\end{tabular}




\subsection{Contents of Macro- and Micronutrients in Leaves of Maiden Apple Trees}

In order to facilitate the inference process, the contents of macro- and micronutrients in the leaves of the maiden apple trees were assessed on the basis of the average values in the four cultivars used in the experiment. The contents differed significantly, depending on the dose of mineral fertiliser, the foliar treatments applied, and the cultivar. The highest nitrogen level was found in the control plants (Table 4 and Figure 1). Lower level were found in the combinations with the two fertilisers, while the lowest levels were found in the combinations with foliar biostimulants. The leaves of the maiden trees of the 'Topaz' cultivar had the highest nitrogen content, whereas the leaves of the 'Gala Schniga' cultivar had the lowest content of this element (Table 4 and Figure 2).

The treatment of the plants with three of the biostimulants used in the experiment (except the Aminoplant) resulted in significantly lower leaf phosphorus contents than in the control combination. The foliar application of two fertilisers resulted in a higher phosphorus content than in the control combination (Table 4 and Figure 1). Only these two fertilisers ensured the optimal phosphorus content in the leaves $(0.16-0.26 \%)$ according to Breś et al. [26]. The highest content of this element was noted in the 'Ligol' cultivar, while the lowest contents were noted in the 'Gala Schniga' and 'Red Boskoop' cultivars (Table 4 and Figure 2).

The leaves of the maiden trees had the highest potassium content after the foliar treatment with the Basfoliar 6-12-6 fertiliser (Table 4 and Figure 1). The treatment of the trees with the Basfoliar 12-4-6+S fertiliser resulted in a significantly lower potassium content than in the control combination, whereas the treatment with the Biamino Plant and Fylloton biostimulants resulted in the same potassium contents. All results exceeded the optimal leaf potassium content (1.00-1.50\%). The 'Topaz' cultivar had the highest leaf potassium content. The 'Red Boskoop' cultivar had the lowest content of this element (Table 4 and Figure 2).

On average, the highest leaf calcium contents were observed after the foliar spray treatment of the maiden trees with the Aminoplant, Bispeed, and Basfoliar 12-4-6+S products (Table 4 and Figure 1). The lowest leaf calcium contents were noted after the treatment with the Biamino Plant biostimulant and in the control plants. The leaves of the 'Ligol' cultivar had the lowest calcium content. The highest content of this element was found in the leaves of the 'Red Boskoop' cultivar (Table 4 and Figure 2).

The foliar treatment of the maiden apple trees with the Basfoliar 6-12-6 fertiliser resulted in the optimal content of magnesium in their leaves $(0.22-0.32 \%)$, which was the best result (Table 4 and Figure 1). The other combinations had low contents of this component $(0.18-0.21 \%)$. The lowest leaf magnesium contents, which was lower than in the control combination, were observed after the treatment of the plants with the Biamino Plant, Bispeed, and Fylloton biostimulants. On average, for all of the considered fertiliser combinations, the maiden trees of the 'Topaz' cultivar had the lowest (deficient) magnesium content in their leaves. The highest (optimal) leaf magnesium content was noted in the trees of the 'Red Boskoop' cultivar (Table 4 and Figure 2).

The treatment of the maiden trees with the Biamino Plant biostimulant resulted in the lowest leaf sodium content. On average for all combinations, 'Topaz' was the cultivar with the lowest content of this element. The treatment of the plants with the Fylloton product resulted in the highest leaf sodium levels, while the highest content was found in the 'Red Boskoop' cultivar (Table 4). 
Table 4. The contents of macronutrients in the leaves of maiden apple trees.

\begin{tabular}{|c|c|c|c|c|c|c|c|c|c|}
\hline \multirow[b]{2}{*}{ Element } & \multirow[b]{2}{*}{ Cultivar } & \multicolumn{8}{|c|}{ Treatment } \\
\hline & & Control & $\begin{array}{l}\text { Amino } \\
\text { Plant }\end{array}$ & $\begin{array}{c}\text { Biamino } \\
\text { Plant }\end{array}$ & Bispeed & Fylloton & $\begin{array}{c}\text { Basfoliar } \\
6-12-6\end{array}$ & $\begin{array}{l}\text { Basfoliar } \\
12-4-6+S\end{array}$ & $\begin{array}{l}\text { Mean for } \\
\text { Cultivar }\end{array}$ \\
\hline \multirow{5}{*}{$\mathrm{N}(\%)$} & Gala Schniga & $1.96 \mathrm{e}-\mathrm{g}$ & $1.72 \mathrm{bc}$ & $1.79 \mathrm{~cd}$ & $1.77 \mathrm{~b}-\mathrm{d}$ & $1.96 \mathrm{e}-\mathrm{g}$ & $1.72 \mathrm{bc}$ & $1.56 \mathrm{a}$ & $1.78 \mathrm{a}$ \\
\hline & Ligol & $2.07 \mathrm{~g}-\mathrm{i}$ & $1.79 \mathrm{~cd}$ & $1.82 \mathrm{~cd}$ & $1.82 \mathrm{~cd}$ & $1.89 \mathrm{~d}-\mathrm{f}$ & 2.17 jk & $2.17 \mathrm{jk}$ & $1.96 \mathrm{c}$ \\
\hline & R. Boskoop & $2.15 \mathrm{ij}$ & $1.86 \mathrm{de}$ & $1.70 \mathrm{bc}$ & $1.87 \mathrm{de}$ & $1.66 \mathrm{ab}$ & $1.98 \mathrm{e}-\mathrm{h}$ & $2.10 \mathrm{hi}$ & $1.90 \mathrm{~b}$ \\
\hline & Topaz & $2.28 \mathrm{kl}$ & $2.00 \mathrm{f}-\mathrm{h}$ & 2.311 & $2.00 \mathrm{f}-\mathrm{h}$ & $2.00 \mathrm{f}-\mathrm{h}$ & $2.24 \mathrm{j}-1$ & 2.351 & $2.16 \mathrm{~d}$ \\
\hline & $\begin{array}{l}\text { Average for } \\
\text { treatment }\end{array}$ & $2.11 \mathrm{~d}$ & $1.84 \mathrm{a}$ & $1.90 \mathrm{~b}$ & $1.86 \mathrm{ab}$ & $1.87 \mathrm{ab}$ & $2.02 \mathrm{c}$ & $2.04 \mathrm{c}$ & \\
\hline \multirow{5}{*}{$\mathrm{P}(\%)$} & Gala Schniga & $0.13 \mathrm{a}-\mathrm{c}$ & $0.12 \mathrm{a}-\mathrm{c}$ & $0.11 \mathrm{ab}$ & $0.13 \mathrm{a}-\mathrm{c}$ & $0.13 \mathrm{a}-\mathrm{c}$ & $0.14 \mathrm{bc}$ & $0.13 \mathrm{a}-\mathrm{c}$ & $0.13 \mathrm{a}$ \\
\hline & Ligol & $0.15 c$ & $0.13 \mathrm{a}-\mathrm{c}$ & $0.13 \mathrm{a}-\mathrm{c}$ & $0.12 \mathrm{a}-\mathrm{c}$ & $0.13 \mathrm{a}-\mathrm{c}$ & $0.24 \mathrm{~d}$ & $0.22 \mathrm{~d}$ & $0.16 c$ \\
\hline & R. Boskoop & $0.13 \mathrm{a}-\mathrm{c}$ & $0.14 \mathrm{bc}$ & $0.13 \mathrm{a}-\mathrm{c}$ & $0.13 \mathrm{a}-\mathrm{c}$ & $0.10 \mathrm{a}$ & $0.13 \mathrm{a}-\mathrm{c}$ & $0.12 \mathrm{a}-\mathrm{c}$ & $0.13 \mathrm{a}$ \\
\hline & Topaz & $0.15 \mathrm{c}$ & $0.13 \mathrm{a}-\mathrm{c}$ & $0.12 \mathrm{a}-\mathrm{c}$ & $0.12 \mathrm{a}-\mathrm{c}$ & $0.14 \mathrm{bc}$ & 0.14 bc & $0.15 \mathrm{c}$ & $0.14 \mathrm{~b}$ \\
\hline & $\begin{array}{l}\text { Average for } \\
\text { treatment }\end{array}$ & $0.14 \mathrm{~b}$ & $0.13 \mathrm{ab}$ & $0.12 \mathrm{a}$ & $0.13 \mathrm{a}$ & $0.13 \mathrm{a}$ & $0.16 \mathrm{c}$ & $0.16 \mathrm{c}$ & \\
\hline \multirow{5}{*}{ K (\%) } & Gala Schniga & $2.13 \mathrm{i}-\mathrm{k}$ & $2.00 \mathrm{e}-\mathrm{h}$ & $1.88 \mathrm{c}-\mathrm{e}$ & $2.13 \mathrm{i}-\mathrm{k}$ & $2.22 \mathrm{k}-\mathrm{m}$ & $2.29 \mathrm{mn}$ & $1.92 \mathrm{c}-\mathrm{f}$ & $2.08 \mathrm{~b}$ \\
\hline & Ligol & $2.04 \mathrm{f}-\mathrm{i}$ & $2.14 \mathrm{i}-1$ & $2.11 \mathrm{~h}-\mathrm{k}$ & $2.14 \mathrm{i}-1$ & $2.11 \mathrm{~h}-\mathrm{k}$ & $2.21 \mathrm{j}-\mathrm{m}$ & $2.14 \mathrm{i}-1$ & $2.12 \mathrm{c}$ \\
\hline & R. Boskoop & $2.09 \mathrm{~h}-\mathrm{j}$ & $1.85 \mathrm{~cd}$ & $1.80 \mathrm{bc}$ & $1.68 \mathrm{ab}$ & $1.60 \mathrm{a}$ & $2.261-n$ & $1.96 \mathrm{~d}-\mathrm{g}$ & $1.86 \mathrm{a}$ \\
\hline & Topaz & $2.12 \mathrm{~h}-\mathrm{k}$ & $2.27 \mathrm{mn}$ & $2.13 \mathrm{i}-\mathrm{k}$ & $2.36 \mathrm{n}$ & $2.05 \mathrm{~g}-\mathrm{i}$ & $2.23 \mathrm{k}-\mathrm{m}$ & $2.14 \mathrm{i}-1$ & 2. $\mathrm{d}$ \\
\hline & $\begin{array}{l}\text { Average for } \\
\text { treatment }\end{array}$ & $2.09 \mathrm{~d}$ & $2.06 \mathrm{~cd}$ & $1.98 \mathrm{a}$ & $2.07 \mathrm{~cd}$ & $1.99 \mathrm{ab}$ & $2.24 \mathrm{e}$ & $2.04 \mathrm{bc}$ & \\
\hline \multirow{5}{*}{$\mathrm{Ca}(\%)$} & Gala Schniga & $0.67 \mathrm{~d}-\mathrm{g}$ & $0.74 \mathrm{~h}-\mathrm{j}$ & $0.68 \mathrm{e}-\mathrm{h}$ & $0.97 \mathrm{~lm}$ & $0.94 \mathrm{kl}$ & 1.10 op & $0.90 \mathrm{k}$ & $0.86 \mathrm{c}$ \\
\hline & Ligol & $0.71 \mathrm{~g}-\mathrm{i}$ & $0.64 \mathrm{~d}-\mathrm{f}$ & $0.62 \mathrm{de}$ & 0.62 de & $0.64 \mathrm{~d}-\mathrm{f}$ & $0.23 \mathrm{a}$ & $0.38 \mathrm{c}$ & $0.55 \mathrm{a}$ \\
\hline & R. Boskoop & 1.04 no & $1.02 \mathrm{mn}$ & $0.76 \mathrm{ij}$ & $0.981-\mathrm{n}$ & $0.79 \mathrm{j}$ & $1.18 \mathrm{r}$ & $1.14 \mathrm{pr}$ & $0.99 \mathrm{~d}$ \\
\hline & Topaz & $0.31 \mathrm{~b}$ & $0.72 \mathrm{~g}-\mathrm{i}$ & $0.71 \mathrm{~g}-\mathrm{i}$ & $0.61 \mathrm{~d}$ & $0.63 \mathrm{~d}-\mathrm{f}$ & $0.37 \mathrm{bc}$ & $0.69 \mathrm{f}-\mathrm{h}$ & $0.58 \mathrm{~b}$ \\
\hline & $\begin{array}{l}\text { Average for } \\
\text { treatment }\end{array}$ & $0.68 \mathrm{a}$ & $0.78 \mathrm{~d}$ & $0.69 \mathrm{a}$ & $0.80 \mathrm{~d}$ & $0.75 \mathrm{c}$ & $0.72 \mathrm{~b}$ & $0.78 \mathrm{~d}$ & \\
\hline \multirow{5}{*}{$\operatorname{Mg}(\%)$} & Gala Schniga & $0.19 \mathrm{c}-\mathrm{f}$ & $0.22 \mathrm{f}-\mathrm{h}$ & $0.21 \mathrm{e}-\mathrm{g}$ & $0.16 \mathrm{bc}$ & $0.19 c-f$ & $0.20 \mathrm{~d}-\mathrm{f}$ & $0.17 b-d$ & $0.19 \mathrm{~b}$ \\
\hline & Ligol & $0.22 \mathrm{f}-\mathrm{h}$ & $0.15 \mathrm{ab}$ & $0.15 \mathrm{ab}$ & $0.16 \mathrm{bc}$ & $0.18 \mathrm{~b}-\mathrm{e}$ & $0.28 \mathrm{jk}$ & $0.26 \mathrm{ij}$ & $0.20 c$ \\
\hline & R. Boskoop. & $0.21 \mathrm{e}-\mathrm{g}$ & $0.30 \mathrm{k}$ & $0.20 \mathrm{~d}-\mathrm{f}$ & $0.25 \mathrm{~h}-\mathrm{j}$ & $0.24 \mathrm{~g}-\mathrm{i}$ & $0.21 \mathrm{e}-\mathrm{g}$ & $0.20 \mathrm{~d}-\mathrm{f}$ & $0.23 \mathrm{~d}$ \\
\hline & Topaz & $0.16 \mathrm{bc}$ & $0.15 \mathrm{ab}$ & $0.16 \mathrm{bc}$ & $0.15 \mathrm{ab}$ & $0.12 \mathrm{a}$ & $0.19 c-f$ & $0.15 \mathrm{ab}$ & $0.15 \mathrm{a}$ \\
\hline & $\begin{array}{l}\text { Average for } \\
\text { treatment }\end{array}$ & $0.20 \mathrm{~b}$ & $0.21 \mathrm{~b}$ & $0.18 \mathrm{a}$ & $0.18 \mathrm{a}$ & $0.18 \mathrm{a}$ & $0.22 \mathrm{c}$ & $0.20 \mathrm{~b}$ & \\
\hline \multirow{5}{*}{$\mathrm{Na}(\%)$} & Gala Schniga & $0.003 \mathrm{a}-\mathrm{c}$ & $0.003 \mathrm{a}-\mathrm{c}$ & $0.002 \mathrm{ab}$ & $0.005 \mathrm{~b}-\mathrm{e}$ & $0.007 \mathrm{~d}-\mathrm{f}$ & $0.004 \mathrm{a}-\mathrm{d}$ & $0.004 \mathrm{a}-\mathrm{d}$ & $0.004 b$ \\
\hline & Ligol & $0.004 \mathrm{a}-\mathrm{d}$ & $0.005 \mathrm{~b}-\mathrm{e}$ & $0.001 \mathrm{a}$ & $0.007 \mathrm{~d}-\mathrm{f}$ & $0.004 \mathrm{a}-\mathrm{d}$ & $0.004 \mathrm{a}-\mathrm{d}$ & $0.004 \mathrm{a}-\mathrm{d}$ & $0.004 \mathrm{~b}$ \\
\hline & R. Boskoop & $0.004 \mathrm{a}-\mathrm{d}$ & $0.005 \mathrm{~b}-\mathrm{e}$ & $0.006 c-f$ & $0.004 \mathrm{a}-\mathrm{d}$ & $0.00 \mathrm{f}$ & $0.006 c-f$ & $0.006 \mathrm{c}-\mathrm{f}$ & $0.006 \mathrm{c}$ \\
\hline & Topaz & $0.004 \mathrm{a}-\mathrm{d}$ & $0.003 \mathrm{a}-\mathrm{c}$ & $0.001 \mathrm{a}$ & $0.001 \mathrm{a}$ & 0.008 ef & $0.002 \mathrm{ab}$ & $0.002 \mathrm{ab}$ & $0.003 \mathrm{a}$ \\
\hline & $\begin{array}{c}\text { Average for } \\
\text { treatment }\end{array}$ & $0.004 \mathrm{~b}$ & $0.004 \mathrm{~b}$ & $0.003 \mathrm{a}$ & $0.004 \mathrm{~b}$ & $0.007 \mathrm{c}$ & $0.004 \mathrm{~b}$ & $0.004 \mathrm{~b}$ & \\
\hline
\end{tabular}

Data followed by the same letters do not differ significantly at $p=0.05$ for each macronutrient according to Tukey's test. The influence of the years was not statistically significant. 


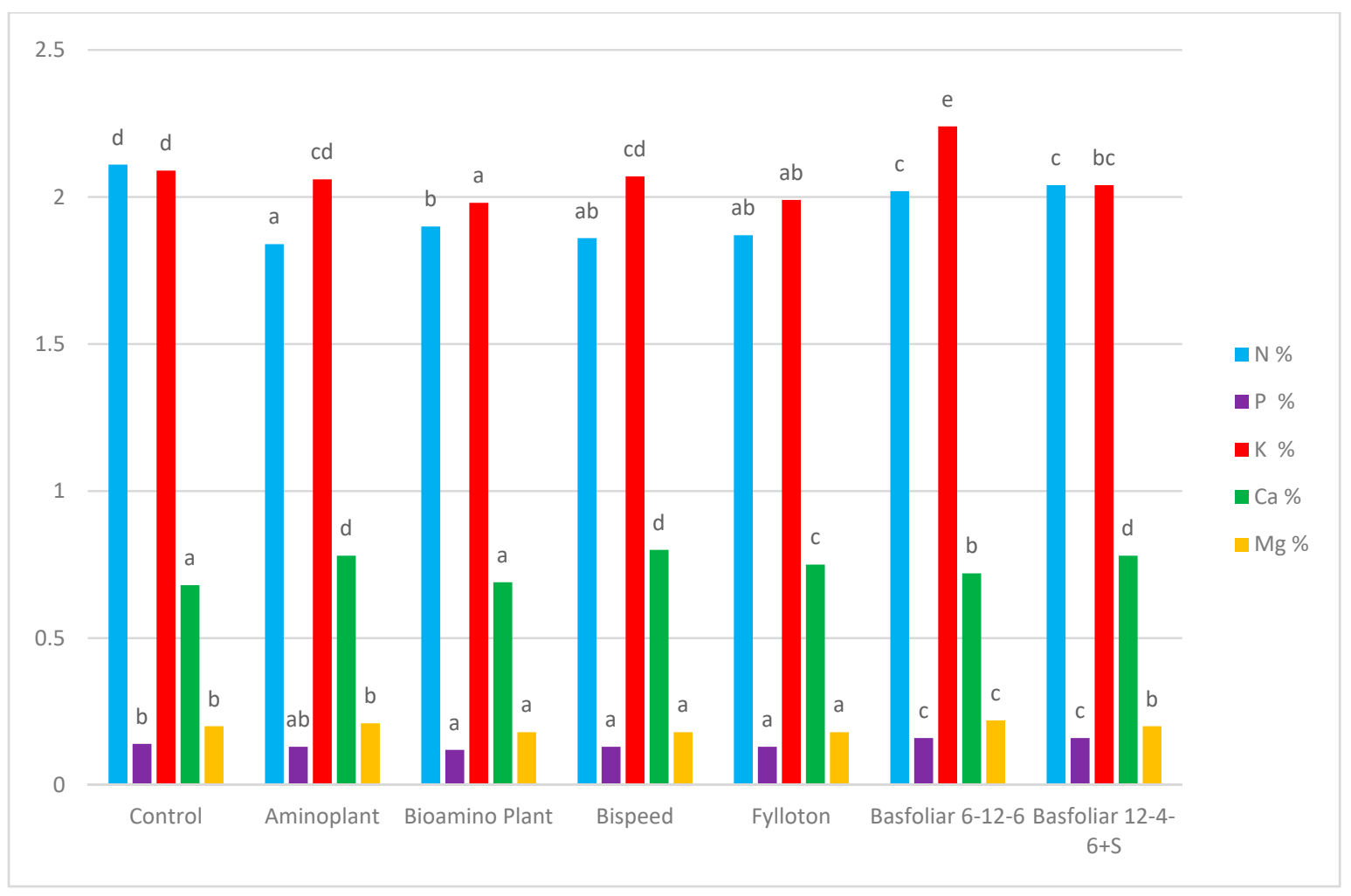

Figure 1. A comparison of the contents of macronutrients in the leaves of maiden apple trees depending on the applied foliar treatment. Data followed by the same letters do not differ significantly at $p=0.05$ for each macronutrient according to Tukey's test.

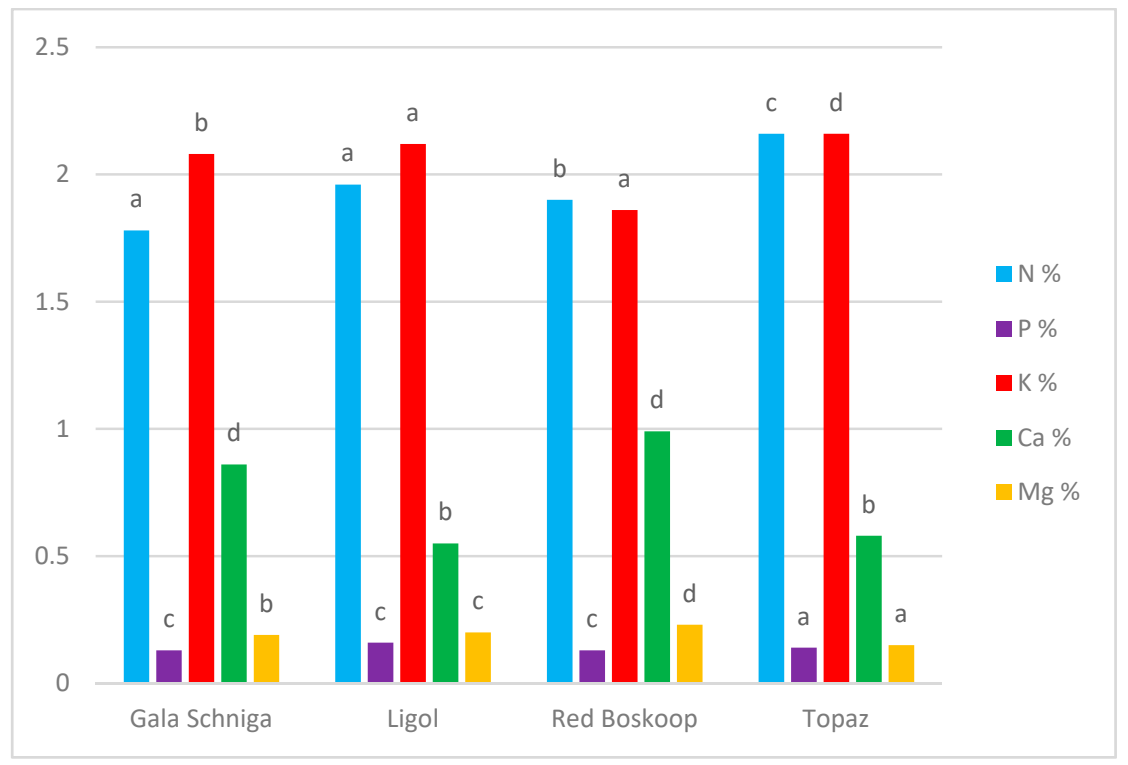

Figure 2. A comparison of the contents of macronutrients in the leaves of maiden apple trees depending on the variety used. Data followed by the same letters do not differ significantly at $p=0.05$ for each macronutrient according to Tukey's test.

The treatment of the plants with the Basfoliar 12-4-6+S fertiliser resulted in a lower leaf iron level than in the control plants (Table 5 and Figure 3). The other foliar treatments resulted in higher contents of this micronutrient than in the control plants. The highest leaf 
iron content was noted in the trees of the 'Red Boskoop' cultivar. The lowest content of this element was found in the leaves of the 'Topaz' cultivar (Table 5 and Figure 4).

The use of the biostimulants resulted in the optimal manganese content in the leaves of the maiden trees (41-100 ppm), but it was low (21-40 ppm) in the other combinations. The treatment of the plants with the Basfoliar 12-4-6+S fertiliser resulted in a lower leaf manganese level than in the control plants (Table 5 and Figure 3). The other foliar treatments resulted in a higher level of this element. The highest manganese level was noted in the leaves of the 'Gala Schniga' and 'Red Boskoop' cultivars. The 'Topaz' cultivar had the lowest leaf manganese content (Table 5 and Figure 4).

The leaf zinc content was higher than in the control plants only after the foliar treatment of the maiden trees with the Basfoliar 6-12-6 product (Table 5 and Figure 3). All the other treatments resulted in lower leaf zinc levels. The 'Red Boskoop' cultivar had the highest zinc content, whereas the 'Gala Schniga' had the lowest level of this element (Table 5 and Figure 4).

The treatment of the plants with the biostimulants resulted in a lower leaf copper content than in the control plants (Table 5 and Figure 3). The two fertilisers applied to the plants resulted in higher contents of this element than in the control combination. The lowest copper level was found in the leaves of the 'Gala Schniga' cultivar, while the highest was found in the 'Topaz' cultivar (Table 5 and Figure 4).

Table 5. The contents of micronutrients in the leaves of maiden apple trees.

\begin{tabular}{|c|c|c|c|c|c|c|c|c|c|}
\hline \multirow{2}{*}{$\begin{array}{l}\text { Micro- } \\
\text { Nutrient }\end{array}$} & \multirow[b]{2}{*}{ Cultivar } & \multicolumn{8}{|c|}{ Treatment } \\
\hline & & Control & $\begin{array}{c}\text { Amino } \\
\text { Plant }\end{array}$ & $\begin{array}{c}\text { Biamino } \\
\text { Plant }\end{array}$ & Bispeed & Fylloton & $\begin{array}{c}\text { Basfoliar } \\
6-12-6\end{array}$ & $\begin{array}{l}\text { Basoliar } \\
12-4-6+S\end{array}$ & $\begin{array}{c}\text { Average for } \\
\text { Cultivar }\end{array}$ \\
\hline \multirow{5}{*}{$\begin{array}{c}\text { Fe } \\
\text { ppm }\end{array}$} & Gala Schniga & $144.4 \mathrm{~h}$ & $165.6 \mathrm{kl}$ & $173.7 \mathrm{~m}$ & 190.7 o & $176.1 \mathrm{mn}$ & $125.8 \mathrm{f}$ & $119.4 \mathrm{e}$ & $156.5 \mathrm{c}$ \\
\hline & Ligol & $101.1 \mathrm{~d}$ & 168.51 & $195.9 \mathrm{p}$ & $164.0 \mathrm{k}$ & $178.4 \mathrm{n}$ & $131.0 \mathrm{~g}$ & $85.8 \mathrm{c}$ & $146.4 \mathrm{~b}$ \\
\hline & R. Boskoop & $199.2 \mathrm{r}$ & $241.2 \mathrm{u}$ & $225.9 \mathrm{t}$ & $268.6 x$ & $219.4 \mathrm{~s}$ & $263.4 \mathrm{w}$ & $152.7 \mathrm{i}$ & $224.3 \mathrm{~d}$ \\
\hline & Topaz & $82.0 \mathrm{~b}$ & $129.1 \mathrm{~g}$ & $160.0 \mathrm{j}$ & $131.8 \mathrm{~g}$ & $147.1 \mathrm{~h}$ & $71.8 \mathrm{a}$ & $79.4 \mathrm{~b}$ & $114.5 \mathrm{a}$ \\
\hline & $\begin{array}{l}\text { Average for } \\
\text { treatment }\end{array}$ & $131.7 \mathrm{~b}$ & $176.1 \mathrm{~d}$ & $188.9 \mathrm{f}$ & $188.8 \mathrm{f}$ & $180.3 \mathrm{e}$ & $148.0 \mathrm{c}$ & 109.3 a & \\
\hline \multirow{5}{*}{$\begin{array}{l}\text { Mn } \\
\text { ppm }\end{array}$} & Gala Schniga & $26.5 \mathrm{bc}$ & $48.6 \mathrm{~m}-\mathrm{O}$ & $43.6 \mathrm{i}-1$ & $59.8 \mathrm{~s}$ & $52.5 p$ & $42.2 \mathrm{~h}-\mathrm{j}$ & $29.0 \mathrm{~cd}$ & $43.2 \mathrm{c}$ \\
\hline & Ligol & $46.51-n$ & $42.4 \mathrm{~h}-\mathrm{k}$ & $41.5 \mathrm{~g}-\mathrm{i}$ & $31.7 \mathrm{~d}$ & $35.0 \mathrm{e}$ & 36.1 ef & $44.8 \mathrm{j}-1$ & $39.7 \mathrm{~b}$ \\
\hline & R. Boskoop & $39.3 \mathrm{gh}$ & $45.5 \mathrm{k}-\mathrm{m}$ & $43.9 \mathrm{i}-1$ & 50.8 op & $41.2 \mathrm{~g}-\mathrm{i}$ & 51.2 op & $25.9 \mathrm{bc}$ & $42.5 \mathrm{c}$ \\
\hline & Topaz & $25.0 \mathrm{ab}$ & 48.8 no & $55.7 \mathrm{r}$ & 49.2 no & $38.5 \mathrm{fg}$ & $25.8 \mathrm{ab}$ & $22.7 \mathrm{a}$ & $38.0 \mathrm{a}$ \\
\hline & $\begin{array}{l}\text { Average for } \\
\text { treatment }\end{array}$ & $34.3 \mathrm{~b}$ & $46.3 \mathrm{e}$ & $46.2 \mathrm{e}$ & $47.9 \mathrm{f}$ & $41.8 \mathrm{~d}$ & $38.8 \mathrm{c}$ & $30.6 \mathrm{a}$ & \\
\hline \multirow{5}{*}{$\begin{array}{c}\mathrm{Zn} \\
\mathrm{ppm}\end{array}$} & Gala Schniga & $21.1 \mathrm{k}$ & $13.3 \mathrm{a}$ & $14.9 \mathrm{~b}$ & $16.1 \mathrm{e}$ & $19.7 \mathrm{j}$ & $24.4 \mathrm{p}$ & $18.8 \mathrm{~h}$ & $18.3 \mathrm{a}$ \\
\hline & Ligol & $15.3 \mathrm{c}$ & $14.8 \mathrm{~b}$ & $17.5 \mathrm{~g}$ & $16.5 \mathrm{f}$ & $15.9 \mathrm{~d}$ & $26.5 \mathrm{t}$ & 22.41 & $18.4 \mathrm{~b}$ \\
\hline & R. Boskoop & $30.7 \mathrm{u}$ & $24.4 p$ & $26.6 \mathrm{t}$ & $26.1 \mathrm{~s}$ & $19.1 \mathrm{i}$ & $39.3 \mathrm{w}$ & $25.4 \mathrm{r}$ & $27.4 \mathrm{~d}$ \\
\hline & Topaz & $22.6 \mathrm{~m}$ & $24.2 \mathrm{o}$ & $24.1 \mathrm{o}$ & $19.6 \mathrm{j}$ & $22.9 n$ & $19.1 \mathrm{i}$ & $21.0 \mathrm{k}$ & $21.9 c$ \\
\hline & $\begin{array}{l}\text { Average for } \\
\text { treatment }\end{array}$ & $22.4 \mathrm{f}$ & $19.2 \mathrm{a}$ & $20.8 \mathrm{~d}$ & $19.6 \mathrm{c}$ & $19.4 \mathrm{~b}$ & $27.3 \mathrm{~g}$ & $21.9 \mathrm{e}$ & \\
\hline \multirow{5}{*}{$\begin{array}{c}\mathrm{Cu} \\
\mathrm{ppm}\end{array}$} & Gala Schiga & $6.6 \mathrm{j}$ & $5.0 \mathrm{~b}$ & $5.0 \mathrm{~b}$ & $6.1 \mathrm{gh}$ & $6.3 \mathrm{i}$ & $6.8 \mathrm{k}$ & $5.5 \mathrm{e}$ & $5.9 \mathrm{a}$ \\
\hline & Ligol & $8.1 \mathrm{~m}$ & $5.3 \mathrm{~cd}$ & $5.0 \mathrm{~b}$ & $4.3 \mathrm{a}$ & $5.2 \mathrm{c}$ & $9.5 \mathrm{r}$ & $8.8 \mathrm{n}$ & $6.6 \mathrm{c}$ \\
\hline & R. Boskoop & $6.1 \mathrm{gh}$ & $5.7 \mathrm{f}$ & $5.4 \mathrm{de}$ & $6.0 \mathrm{~g}$ & $4.4 \mathrm{a}$ & $8.7 \mathrm{n}$ & 7.11 & $6.2 \mathrm{~b}$ \\
\hline & Topaz & $10.0 \mathrm{~s}$ & $6.9 \mathrm{k}$ & $6.2 \mathrm{hi}$ & $6.5 \mathrm{j}$ & $9.3 \mathrm{p}$ & $9.1 \mathrm{o}$ & $10.0 \mathrm{~s}$ & $8.3 \mathrm{~d}$ \\
\hline & $\begin{array}{c}\text { Average for } \\
\text { treatment }\end{array}$ & $7.7 \mathrm{~d}$ & $5.7 \mathrm{~b}$ & $5.4 \mathrm{a}$ & $5.7 \mathrm{~b}$ & $6.3 c$ & $8.5 \mathrm{f}$ & $7.9 \mathrm{e}$ & \\
\hline
\end{tabular}

Data followed by the same letters do not differ significantly at $p=0.05$ for each micronutrient according to Tukey's test. The influence of the years was not statistically significant. 


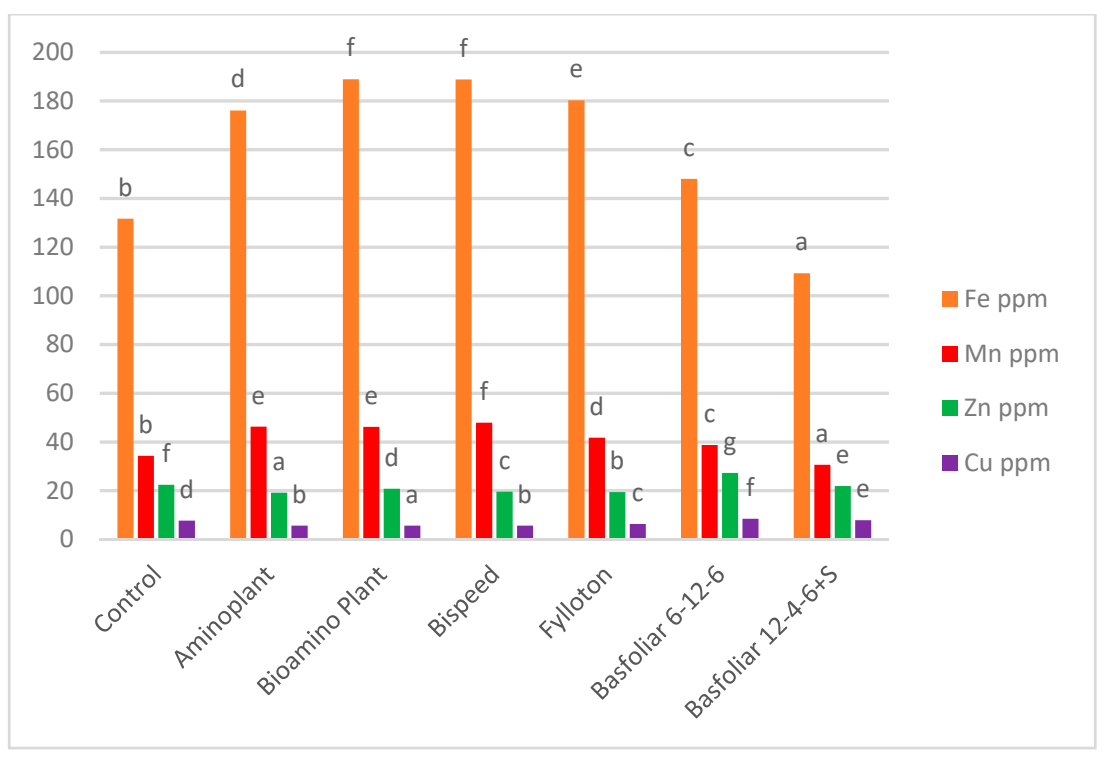

Figure 3. A comparison of the contents of micronutrients in the leaves of maiden apple trees depending on the applied foliar treatment. Data followed by the same letters do not differ significantly at $p=0.05$ for each micronutrient according to Tukey's test.

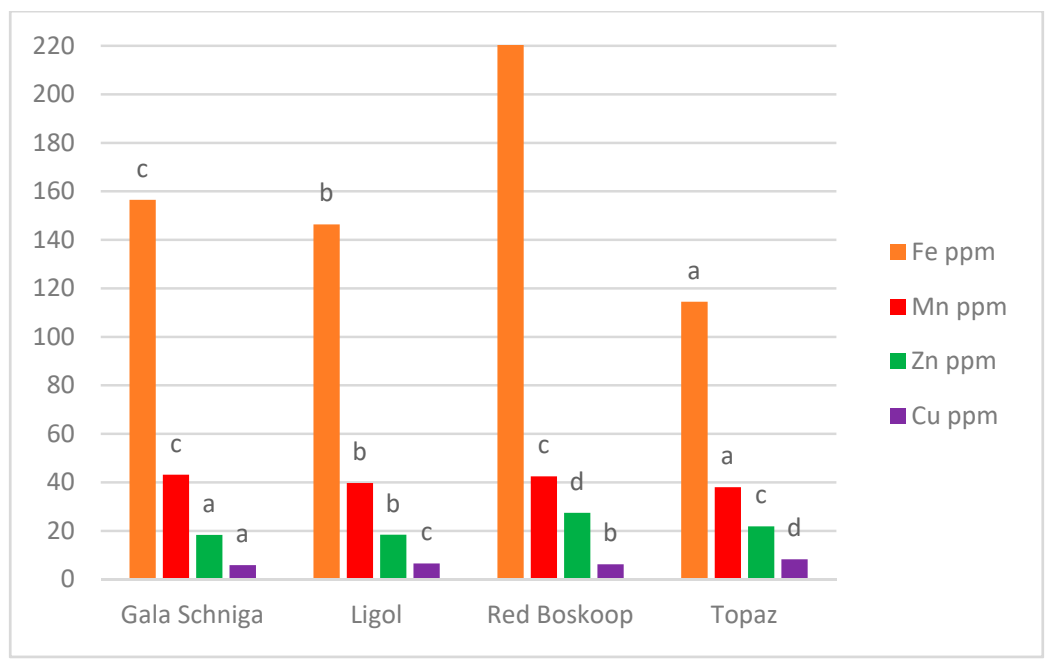

Figure 4. A comparison of the content of micronutrients in leaves of maiden apple trees depending on the variety used. Data followed by the same letters do not differ significantly at $p=0.05$ for each micronutrient according to Tukey's test.

\section{Discussion}

\subsection{The Contents of Soluble Forms of Chemicals in Soil}

The soil $\mathrm{pH}$ decreased when the dose of mineral fertiliser was reduced by half. The results of our experiment were consistent with the observations made by the authors of other studies [28-31], according to which the use of chemical fertilisers can acidify the soil, affecting its microbiological properties, the availability of nutrients, the growth of plant roots, and consequently leading to decreased yields. Grzyb et al. [25] also found that a full dose of mineral fertiliser increased the soil $\mathrm{pH}$ in an apple tree nursery as compared with the effect of biopreparations applied into the soil. In our experiment, the lower dose of the mineral fertiliser decreased the salinity of the soil and its contents of S-SO ${ }_{4}, \mathrm{P}_{-} \mathrm{PO}_{4}$, $\mathrm{K}, \mathrm{Mg}, \mathrm{Na}, \mathrm{Zn}$, and $\mathrm{Cu}$. Filipczak et al. [20] made similar observations to the results of our experiment. They found that the foliar or soil application of biostimulants in a strawberry plantation caused the soil phosphorus content to range from medium to high, 
the potassium content from low to high, and the magnesium content from low to medium. The K/Mg ratio was correct in most of the experimental combinations. Grzyb et al. [25] noted similar nitrogen and phosphorus contents in the soil in all experimental combinations. The researchers observed that the full dose of mineral fertiliser and the application of the Florovit Eko and Florovit Pro Natura fertilisers into the soil significantly increased the level of potassium as compared with the effects of fertilisation with biopreparations. This result was consistent with our observations. The experiment conducted by these authors [25] also showed that the high accumulation of potassium in the soil after full mineral fertilisation resulted in a lower content of available forms of magnesium. This dependence was not observed in our experiment.

In our experiment, a lower dose of the mineral fertiliser resulted in lower soil micronutrient contents, except for iron. According to Kleiber et al. [32], low soil nutrient contents (especially micronutrients such as $\mathrm{Fe}, \mathrm{Cu}, \mathrm{Zn}, \mathrm{Mn}$, and B) may be caused by low soil $\mathrm{pH}$ and low salinity. These factors may have been the causes of the low contents of most micronutrients in our experiment.

\subsection{The Contents of Macro- and Micronutrients in the Leaves of Maiden Apple Trees}

Our experiment showed that the biostimulants and foliar fertilisers had diverse effects on the contents of macro- and micronutrients in the leaves of the four cultivars of maiden apple trees in the nursery. According to Świerczyński et al. [24], it is difficult to compare the results of studies on the contents of nutrients in leaves because they depend on various factors, including the compositions of the preparations used, the weather conditions, the soil abundance, as well as the plant species and cultivar. Our experiment showed that the foliar treatment of the maiden apple trees with the fertilisers guaranteed higher contents of nutrients in their leaves than with the use of biostimulants, which resulted in lower levels of most of the nutrients than in the control plants. However, this did not prevent us from obtaining better growth results for the same maiden apple trees than those described in the previous research by the same authors [33]. All of the maiden growth parameters described in this publication obtained from the same experiment after treatment with biostimulants and foliar fertilisers showed higher values than those obtained from the control combination with the full dose of mineral fertilisation. This proves the potential possibility of reducing the mineral fertilisation of the soil while maintaining the expected growth parameters for maiden apple trees in nursery settings. In the conducted experiment, no positive effect of the biostimulants used, even those containing nitrogen such as Aminoplant and Bioamino Plant, was found to increase the content of this element in the leaves. The lack of influence of the tested nitrogen biostimulators on the content of this nutrient in the leaves may be due to the fact that these biostimulators most effectively improved the growth of maiden apple trees, as presented in the previous publication [33]. Nitrogen contained in biostimulants, which is easier for plants to absorb, intensifies their growth. Rathore et al. [15] observed another dependence at a full dose of mineral fertiliser. The researchers found that the soybeans treated with biostimulants had higher contents of $\mathrm{N}$, $\mathrm{P}, \mathrm{K}$, and $\mathrm{Mg}$. Likewise, other authors $[18,34,35]$ also observed that the foliar treatment of various plant species with various biostimulants increased the leaf nitrogen content. Garcia et al. [36] observed that the foliar application of a biostimulant containing amino acids, peptides, and nutrients increased the levels of potassium, calcium, magnesium, iron, copper, and zinc in tomato leaves, which improved the growth and development of the plants. Similarly, the foliar application of biostimulants alone or in combination with potassium and zinc increased the levels of $\mathrm{N}, \mathrm{P}, \mathrm{K}, \mathrm{Ca}, \mathrm{Mg}$, and $\mathrm{Zn}$ in mandarin leaves [37]. Rouphael et al. [38] observed that protein hydrolysates increased the $\mathrm{K}$ and $\mathrm{Mg}$ contents in spinach leaves, being more effective than the seaweed extract. Abdala [39] observed that the Moringa oleifera extract increased the contents of N, P, K, Ca, Mg, and Fe in rocket leaves (Eruca vesicaria subsp. sativa). On the other hand, Soppelsa et al. [40] applied several biostimulants to strawberry leaves but they did not increase the concentration of macronutrients. According to Filipczak et al. [20], neither the soil nor foliar biostimulants 
used in their study had significant influence on the contents of minerals in strawberry leaves. Likewise, Chitu et al. [41] could not confirm the effects of biostimulants on the contents of macronutrients in apple leaves. The differences between the results of our experiment and the findings of other authors' studies on the influence of biostimulants on the contents of minerals in leaves were caused by the fact that only half the dose of the mineral fertiliser was used in our experiment, whereas the other authors used a full dose.

Studies have proven that preparations based on marine algae increase the contents of $\mathrm{K}, \mathrm{Ca}$, and $\mathrm{Mg}$ in lettuce leaves [42], as well as the contents of N, P, K, Ca, Zn, and Fe in tomato leaves [43]. Similarly, Turan and Köse [18] noted that the foliar treatment of young grapevines with a marine algae extract increased the plants' uptake of $\mathrm{N}, \mathrm{P}$, $\mathrm{K}, \mathrm{Ca}, \mathrm{Mg}, \mathrm{Fe}, \mathrm{Zn}, \mathrm{Mn}$, and $\mathrm{Cu}$. In our experiment, the preparation based on marine algae (Fylotton) did not increase the contents of nutrients in the leaves of the maiden apple trees. However, the concentration of this biostimulator used for the treatment of vegetable crops as recommended by the producer may not be sufficient for fast-growing perennial plants such as maiden apple trees. The increased contents of nutrients after the use of the seaweed extract was attributed to the increased permeability of the cell membrane [44]. According to some authors [45,46], the marine algae extract upregulates the expression of the nitrogen-transporting gene and improves nitrogen detection and auxin transport. Battacharyya et al. [47] observed that the marine algae extract improved nitrogen accumulation. Neither in our experiment nor in a similar experiment [25] did the preparation based on marine algae increase the leaf nitrogen content. None of the foliar treatments resulted in a higher leaf nitrogen content than in the control plants.

In our experiment, the phosphorus level was the same as in the control plants only after the use of one biostimulant, i.e., Aminoplant. Likewise, in another experiment [25] the leaf phosphorus content was similar to the content of this element in the control plants only after one amino-acid-based preparation. On the other hand, Von Bennewitz et al. [48] observed that biostimulants increased the phosphorus content in apple leaves. Many authors $[14,15,18]$ have observed that biostimulants based on seaweed extracts improve the phosphorus uptake by plants. No such dependence was observed in our experiment after the treatment of the plants with the Fylloton product.

None of the biostimulants tested in our experiment increased the leaf potassium content, whereas the marine algae extract decreased the content of this element. Our observation was partly confirmed by the results of the study by Shehata et al. [19], who found that the foliar treatment of celeriac plants with amino acid preparations did not have a significant influence on the leaf potassium content and that the marine algae extract increased the content of this element. Grzyb et al. [25] found that the treatment of maiden apple trees with the Florovit Eko and Pro Natura fertilisers significantly increased the leaf potassium content, whereas biostimulants decreased the level of this element. Likewise, in our experiment the Basfoliar 6-12-6 fertiliser increased the leaf potassium content, which was higher than in the control plants, whereas most of the other biostimulants decreased this content. This may indicate that foliar application of potassium-based fertilisers such as the applied Basfoliar 6-12-6 increases the content of this element in the leaves of plants. Grzyb et al. [25] observed that the high content of potassium in the leaves of maiden cherry trees caused significantly decreased contents of magnesium and calcium. This effect was not observed in our study, because the high potassium content in the leaves of the maiden apple trees mostly did not result in low calcium levels. The leaf magnesium content decreased only in some combinations.

Most of the biostimulants used in our experiment increased the calcium content and decreased the magnesium content in the leaves of the maiden apple trees. The results of our study were different from the findings of another experiment conducted in a nursery [25]. Maini [49] concluded that apple trees could take up calcium better if applied together with a biostimulant. This effect may also have taken place in our experiment.

In our experiment, the following biostimulants had the best effect on the contents of minerals in the maiden apple trees grown in the nursery: Aminoplant $(\mathrm{K}, \mathrm{Ca}, \mathrm{Mg}, \mathrm{Mn})$, 
Fylloton (Na, Fe, Zn, Cu), Bispeed ( $\mathrm{Ca}, \mathrm{Fe}, \mathrm{Mn}$ ), and Biamino Plant (N, Fe, Zn). The Bioamino Plant biostimulant, which contained three micronutrients (Fe, Mn, Zn), increased the contents of two of them (Fe, Mn). Similarly, the two foliar fertilisers applied in our experiment increased the zinc and copper contents in the leaves because they contained these elements. According to Westwood [50], amino acids have a chelating effect. They increase the permeability of the cell membrane and facilitate the absorption and transport of microelements inside plants. In our experiment, this dependence was observed for iron and manganese but not for zinc or copper. Maini [49] observed that the foliar application of the Aminoplant biostimulant increased the uptake of micronutrients and concluded that it could be used with $\mathrm{FeSO}_{4}$ to combat iron deficiency symptoms. This effect was also observed in our experiment. Soppelsa et al. [40] used several biostimulants and found that they increased the concentrations of some micronutrients (Fe, $\mathrm{Zn}$, and $\mathrm{Si}$ ). In our experiment, this effect was observed for iron. However, not all of the biostimulants increased the copper content. According to Allen et al. [51], plants react in a specific way to the type of fertiliser applied. Treatment with biostimulants increases the contents of soil minerals and improves the growth and development of plants. This thesis is consistent with the results of other studies [52-56]. In the considered experiment, the foliar treatment of maiden apple trees with biostimulants and fertilisers did not improve their nutritional status in terms of the contents of macronutrients and some micronutrients. However, based on previously published results [33], this did not have a negative impact on their growth.

The maiden apple tree cultivars used in our experiment differed in their leaf contents of macro- and micronutrients. Other authors [24,25,56] also observed species- or cultivardependent differences in the effects of the same biostimulants and fertilisers on the nutrition of plants.

\section{Conclusions}

The half dose of mineral fertiliser resulted in lower soil $\mathrm{pH}$ and salinity in the nursery, which undoubtedly improved the soil properties. However, it also reduced the soil abundance of macronutrients and some micronutrients as compared with the full dose of mineral fertiliser. The foliar application of the biostimulants combined with the reduced dose of mineral fertiliser resulted in worse nutrition of the maiden apple trees, which were less abundant in macroelements (except for calcium) and microelements (except for iron and manganese). On the other hand, the use of two fertilisers improved the nutrition of maiden apple trees for some macronutrients (phosphorus, calcium) and micronutrients (zinc, copper) in relation to control plants. Cultivar-dependent differences were observed in the contents of nutrients in the leaves of the maiden apple trees after the foliar treatments. It seems advisable to combine foliar fertilisers with biostimulants, although this requires further research. This will enable a full answer to the question of whether the use of foliar treatments is justified in the production of maiden apple trees, which are an important fruit tree species in Europe.

Author Contributions: S.Ś. and A.A. contributed to the study conception and design. Material preparation, data collection, and data analyses were performed by S.Ś. and A.A. The first draft of the manuscript was written by S.S. and all authors commented on the previous version of the manuscript. All authors have read and agreed to the published version of the manuscript.

Funding: Publication was co-financed within the framework of the Polish Ministry of Science and Higher Education's program 'Regional Initiative Excellence' in the year 2019-2022 (No. 005/RID/2018/19), financing amount 1,200,000 PLN.

Data Availability Statement: Data sharing not applicable.

Conflicts of Interest: The authors declare that there are no conflict of interest related to this article. 


\section{References}

1. Dong, S.; Neilsen, D.; Neilsen, G.H.; Fuchigami, L.H. Foliar $\mathrm{N}$ application reduces soil $\mathrm{NO}_{3}-\mathrm{N}$ leaching loss in apple orchards. Plant Soil 2005, 268, 357-366. [CrossRef]

2. Khan, I.A.; Khatri, A.; Nizamani, G.S.; Siddiqui, M.A.; Raza, S.; Dahar, N. Effect of NPK fertilizers on the growth of sugarcane clone AEC 86347 developed at Nia. Tando Jam. Pak. J. Bot. 2005, 37, 355360. [CrossRef]

3. Abdelaziz, M.; Pokluda, R.; Abdelwahab, M. Inflence of compost, microorganisms and NPK fertilizer upon growth, chemical composition and essential oil production of Rosmarinus officinalis L. Not. Bot. Hort. Agrobot. 2007, 35, 86-90. [CrossRef]

4. Kang, M.S.; Aulakh, M.S.; Dhiman, J.S. Agricultural development in Punjab: Problems, possible solution and new initatives. Alumni Association, College of Agriculture, Punjab Agricultural University. Ludhiana 2008, 38, $26-34$.

5. Wójcik, P. Uptake of mineral nutrients from foliar fertilization. J. Fruit Ornam. Plant Res. 2004, 12, 201-218.

6. Pfeiffer, B.; Eis, B.; Zimmer, J.; Fieger-Metag, N. Optimizing crop loading of apples and pears-results (foliar fertilizers, thinning). In Proceedings of the Ecofruit-13th International Conference on Cultivation Technique and Phytopathological Problems in Organic Fruit-Growing, Weinsberg, Germany, 18-20 February 2008; pp. 324-329.

7. Naseri, L.; Arzani, K.; Babalar, M. Foliar boron, copper and manganese uptakes and cocentrations of apple leaves cv. Golden Delicious on M9 and B9 rootstocks. Acta Hortic. 2002, 594, 237-243.

8. Amiri, M.E.; Fallahi, E.; Golchin, A. Influence of foliar and ground fertilization on yield, fruit quality, and soil, leaf, and fruit mineral nutrients in apple. J. Plant Nutr. 2008, 31, 515-525. [CrossRef]

9. Karim, M.R.; Zhang, Y.Q.; Zhao, R.R.; Chen, X.P.; Zhang, F.S.; Zou, C.Q. Alleviation of drought stress in winter wheat by late foliar application of zinc, boron, and manganese. J. Plant Nutr. Soil Sci. 2012, 175, 142-151. [CrossRef]

10. Thalheimer, M.; Paoli, N. Effectiveness of various leaf-applied biostimulators on productivity and fruit quality of apple. Acta Hortic. 2002, 594, 335-339. [CrossRef]

11. Trivedi, P.C. Advantage in Plant Physiology; International Publishing House New Delhi: New Delhi, India, $2006 ;$ pp. $213-215$.

12. Colla, G.; Nardi, S.; Cardarelli, M.; Ertani, A.; Lucini, L.; Canaguier, R.; Rouphael, Y. Protein hydrolysates as biostimulants in horticulture. Sci. Hortic. 2015, 196, 28-38. [CrossRef]

13. Lucini, L.; Rouphael, Y.; Cardarelli, M.; Canaguier, R.; Kumar, P.; Colla, G. The effect of a plant-derived biostimulant on metabolic profiling and crop performance of lettuce grown under saline conditions. Sci. Hortic. 2015, 182, 124-133. [CrossRef]

14. Mancuso, S.; Azzarello, E.; Mugnai, S.; Briand, X. Marine bioactive substances (IPA extract) improve foliar ion uptake and water stress tolerance in potted Vitis vinifera plants. Adv. Hortic. Sci. 2006, 20, 156-161.

15. Rathore, S.S.; Chaudhary, D.R.; Boricha, G.N.; Ghosh, A.; Bhatt, B.P.; Zodape, S.T.; Patolia, J.S. Effect of seaweed extract on the growth, yield and nutrient uptake of soybean (Glycine max) under rainfed conditions. S. Afr. J. Bot. 2009, 75, 351-355. [CrossRef]

16. Zodape, S.T.; Kawarkhe, V.J.; Patolia, J.S.; Warade, A.D. Effect of liquid seaweed fertilizer on yield and quality of okra (Abelmoschus esculentus L.). J. Sci. Ind. Res. 2008, 67, 1115-1117.

17. Jannin, L.; Arkoun, M.; Ourry, A.; Laîné, P.; Goux, D.; Garnica, M.; Fuentes, M.; Francisco, S.S.; Baigorri, R.; Cruz, F.; et al. Microarray analysis of humic acid effects on Brassica napus growth: Involvement of N, C and S metabolisms. Plant Soil 2012, 359, 297-319. [CrossRef]

18. Turan, M.; Köse, C. Seaweed extracts improve copper uptake of grapevine. Acta Agric. Scand. Plant Sci. 2004, 54, 213-220. [CrossRef]

19. Shehata, S.M.; Abdel-Azem, H.S.; Abou El-Yazied, A.; El-Gizawy, A.M. Effect of foliar spraying with amino acids and seaweed extract on growth chemical constitutes, yield and its quality of celeriac plant. Eur. J. Sci. Res. 2011, 58, $257-265$.

20. Filipczak, J.; Żurawicz, E.; Sas Paszt, L. Wpływ wybranych biostymulatorów na wzrost i plonowanie roślin truskawki ‘Elkat’ (The influence of selected biostimulants on the growth and yielding of strawberry plants 'Elkat'). Zesz. Nauk. ISiK Skiern. 2016, $24,43-58$.

21. Furuya, S.; Umemiya, Y. The influence of chemical forms on foliar-applied nitrogen absorption for peach trees. Acta Hortic. 2002, 594, 97-103. [CrossRef]

22. De Pascale, S.; Rouphael, Y.; Colla, G. Plant biostimulants: Innovative tool for enhancing plant nutrition in organic farming. Eur. J. Hortic. Sci. 2017, 82, 277-285. [CrossRef]

23. Świerczyński, S.; Stachowiak, A. The influence of three fertilizers and preparation Gibrescol used as the foliage spraying on the growth and nutritional status of maiden apple trees in a nursery. Ann. UMCS Sec. E Agric. 2009, 64, 78-85.

24. Świerczyński, S.; Borowiak, K.; Bosiacki, M.; Urbaniak, M.; Malinowska, A. Estimation of the growth of 'Vanda' maiden sweet cherry trees on three rootstocks and after application of foliar fertilization in a nursery. Acta Sci. Pol. Hortorum Cultus 2019, 18, 109-118. [CrossRef]

25. Grzyb, Z.S.; Piotrowski, W.; Sas Paszt, L.; Paśḱko, M. Badania wstępne nad wpływem różnych biopreparatów na zmiany odczynu i zawartość składników w glebie i liściach okulantów jabłoni i wiśni (Preliminary studies on the influence of various biopreparations on changes in the reaction and the content of components in the soil and leaves of apple and cherry maiden trees). J. Res. Appl. Agric. Eng. 2013, 58, 198-203.

26. Breś, W.; Golcz, A.; Komosa, A.; Kozik, E.; Tyksiński, W. Żywienie Roślin Ogrodniczych. (Nutrition of Horticultural Plants); Wydawnictwo Uniwersytetu Przyrodniczego w Poznaniu: Poznan, Poland, 2009; p. 3.

27. Lipiński, W. Zasobność gleb Polski w mikroelementy. (The abundance of micronutrients in Polish soils). Studia Rap. IUNG-PIB 2013, 34, 121-131. 
28. Sas Paszt, L.; Żurawicz, E. The influence of nitrogen forms on root growth and $\mathrm{pH}$ changes in the rizosphere of strawberry plants. Acta Hort. 2004, 649, 217-221. [CrossRef]

29. Ryabtseva, T.V.; Kapichnikova, N.G.; Mikhailovskaya, N.A. Influence of soil application of biological and mineral fertilizers on the growth, yield, and fruit biochemical components of 'charavnitsa' apple, and on some agrochemical soil characteristics. Acta Sci. Pol. Hortorum Cultus 2005, 4, 59-67.

30. Van Diepeningen, A.D.; de Vos, O.J.; Korthals, G.W.; van Bruggen, A.H. Effects of organic versus conventional management on chemical and biological parameters in agricultural soils. Appl. Soil Ecol. 2006, 31, 120-135. [CrossRef]

31. Wang, L.; Li, J.; Yang, F.; Yaoyao, E.; Raza, W.; Huang, Q.; Shen, Q. Application of bioorganic fertilizer significantly increased apple yields and shaped bacterial community structure in orchard soil. Microb. Ecol. 2017, 73, 404-416. [CrossRef]

32. Kleiber, T.; Markiewicz, B.; Kleiber, A. Wybrane właściwości chemiczne gleb zgrupowania “Szwajcaria Lwówecka” (Selected chemical properties of the soils of the "Lwówecka Switzerland" group). Apar. Badaw. Dydakt. 2010, 4, 69-74.

33. Świerczyński, S.; Antonowicz, A.; Bykowska, J. The Effect of the Foliar Application of Biostimulants and Fertilisers on the Growth and Physiological Parameters of Maiden Apple Trees Cultivated with Limited Mineral Fertilisation. Agronomy 2021, 11, 1216. [CrossRef]

34. Halpern, M.; Bar-Tal, A.; Ofek, M.; Minz, D.; Muller, T.; Yermiyahu, U. The use of biostimulants for enhancing nutrient uptake. Adv. Agron. 2015, 130, 141-174. [CrossRef]

35. Cristiano, G.; Pallozzi, E.; Conversa, G.; Tufarelli, V.; De Lucia, B. Effects of an Animal-Derived Biostimulant on the Growth and Physiological Parameters of Potted Snapdragon (Antirrhinum majus L.). Front. Plant Sci. 2018, 9, 861. [CrossRef] [PubMed]

36. Garcia, A.L.; Madrid, R.; Gimeno, V.; Rodriguez-Ortega, W.M.; Nicolas, N.; Garcia-Sanchez, F. The effects of amino acids fertilization incorporated to the nutrient solution on mineral composition and growth in tomato seedlings. Span. J. Agric. Res. 2011, 9, 852-861. [CrossRef]

37. Nasir, M.; Khan, A.S.; Basra, S.A.; Malik, A.U. Foliar application of moringa leaf extract, potassium and zinc influence yield and fruit quality of Kinnow'mandarin. Sci. Hortic. 2016, 210, 227-235. [CrossRef]

38. Rouphael, Y.; Giordano, M.; Cardarelli, E.; Cozzolino, E.; Mori, M.; Kyriacou, M.; Bonini, P.; Colla, G. Plant and seaweedbased extract increase yield but differentially modulate nutritional quality of greenhouse spinach through biostymulant action. Agronomy 2018, 8, 126. [CrossRef]

39. Abdalla, M.M. The potential of Moringa oleifera extract as a biostimulant in enhancing the growth, biochemical and hormonal contents in rocket (Eruca vesicaria subsp. sativa) plants. Int. J. Plant Physiol. Biochem. 2013, 5, 42-49. [CrossRef]

40. Soppelsa, S.; Kelderer, M.; Casera, C.; Bassi, M.; Robatscher, P.; Matteazzi, A.; Andreotti, C. Foliar applications of biostimulants promote growth, yield and fruit quality of strawberry plants grown under nutrient limitation. Agronomy 2019, 9, 483. [CrossRef]

41. Chitu, V.; Chitu, E.; Marin, F.C.; Ionita, A.D.; Cirjaliu-Murgea, M.; Filipescu, L. Effects of foliar ecological products application on apple growth, yield and quality. Acta Hortic. 2010, 868, 409-416. [CrossRef]

42. Crouch, I.J.; Beckett, R.P.; Van Staden, J. Effect of seaweed concentrate on the growth and mineral nutrition of nutrient-stressed lettuce. J. Appl. Phycol. 1990, 2, 269-272. [CrossRef]

43. Dobromilska, R.; Mikiciuk, M.; Gubarewicz, K. Evaluation of cherry tomato yielding and fruit mineral composition after using of Bio-algeen S-90 preparation. J. Elem. 2008, 13, 491-499.

44. Kuwada, K.; Wamocho, L.S.; Utamura, M.; Matsushita, I.; Ishii, T. Effect of red and green algal extracts on hyphal growth of arbuscular fungi, and on mycorrhizal development and growth of papaya and passionfruit. Agron. J. 2006, 98, 1340-1344. [CrossRef]

45. Krouk, G.; Lacombe, B.; Bielach, A.; Perrine-Walker, F.; Malinska, K.; Mounier, E.; Hoyerova, K.; Tillard, P.; Leon, S.; Ljung, K. Nitrate-regulated auxin transport by NRT1.1 defines a mechanism for nutrient sensing in plants. Dev. Cell 2010, 18, 927-937. [CrossRef] [PubMed]

46. Castaings, L.; Marchive, C.; Meyer, C.; Krapp, A. Nitrogen signalling in Arabidopsis: How to obtain insights into a complex signalling network. J. Exp. Bot. 2011, 62, 1391-1397. [CrossRef] [PubMed]

47. Battacharyya, D.; Babgohari, M.Z.; Rathor, P.; Prithiviraj, B. Seaweed extracts as biostimulants in horticulture. Sci. Hortic. 2015, 196, 39-48. [CrossRef]

48. Von Bennewitz, E.; Hlušek, J.; Lošák, T. Nutritional status, vegetative and generative behaviour of apple trees after the application of two biopreparations. Acta Univ. Agric. Silvic. Mendel. Brun. 2014, 56, 13-18.

49. Maini, P. The experience of the first biostimulant, based on amino acids and peptides: A short retrospective review on the laboratory researches and the practical results. Fertil. Agrorum 2006, 1, $29-43$.

50. Westwood, M.N. Temperate-Zone Pomology. Physiology and Culture; Timber Press: Portland, OR, USA, 1993.

51. Allen, M.F.; Swenson, W.; Querejeta, J.I.; Egerton-Warburton, L.M.; Treseder, K.K. Ecology of mycorrhizae: A conceptual framework for complex interactions among plants and fungi. Annu. Rev. Phytopathol. 2003, 41, 271-303. [CrossRef] [PubMed]

52. Wójcik, P.; Wójcik, M. Growth and nutrition of M.26 EMLA apple rootstock as influence by titanium fertilization. J. Plant Nutr. 2001, 24, 1575-1588. [CrossRef]

53. Wójcik, P. Vigor and nutrition of apple trees in nursery as influenced by titanium sprays. J. Plant Nutrit. 2002, 25, 1129-1138. [CrossRef] 
54. Serrano, M.; Martinem-Romero, D.; Castillo, S.; Guillen, F.; Valero, D. Effect of preharvest sprays containing calcium, magnesium and titanium on the quality of peaches and nectarines at harvest and during postharvest storage. J. Sci. Food Agric. 2004, 84, 1270-1276. [CrossRef]

55. Malusà, E.; Sas Paszt, L.; Popińska, W.; Żurawicz, E. The effect of a substrate containing arbuscular mycorrhizal fungi and rhizosphere microorganisms (Trichoderma, Bacillus, Pseudomonas and Streptomyces) and foliar fertilization on growth response and rhizosphere $\mathrm{pH}$ of three strawberry cultivars. Int. J. Fruit Sci. 2007, 6, 25-41. [CrossRef]

56. Skupień, K.; Oszmianski, J. Influence of titanium treatment on antioxidants and antioxidant activity of strawberries. Acta Sci. Pol. Technol. Aliment. 2007, 6, 83-94. 